\title{
Rancang Bangun Bimbingan Konseling Online
}

\author{
Nur Cahyo Hendro Wibowo ${ }^{1}$, Flora Ima Milenia², Faris Hifzhuddin Azmi ${ }^{3}$ \\ 123 Universitas Islam Negeri Walisongo Semarang
}

\begin{abstract}
The development of science and technology has brought humans to modern civilization, a civilization that is characterized by many uses of technology to help human activities. The phenomenon of information technology and global telecommunications creates a paradigm of open society, which is a reality where there are no obstacles and boundaries that prevent interaction with one another. In this study using Research and Development Methods, research methods used to produce certain products and test product effectiveness. The results of the Online Counseling product are internet counseling which generally refers to professions related to mental health services through internet communication technology. Counseling was developed using communication technology from the simplest using e-mail, chat sessions, PC-to-PC telephone sessions for use with a webcam (live video session), which obviously uses a computer and the internet. Online counseling is a client and counselor who communicates using video and audio streaming.
\end{abstract}

Keywords: Computer, Internet, Counselin

\begin{abstract}
Abstrak
Perkembangan ilmu pengetahuan dan teknologi telah membawa manusia menuju peradaban modern, suatu peradaban yang ditandai dengan banyak pemanfatan teknologi untuk membantu aktifitas manusia. Fenomena teknologi informasi dan telekomunikasi global menciptakan suatu kecenderungan paradigma masyarakat terbuka, yaitu suatu kenyataan dimana tidak ada sekat dan batas yang menghalangi untuk saling berinteraksi. Pada penelitian ini menggunakan Metode Research and Development, metode penelitian yang digunakan untuk menghasilkan produk tertentu dan menguji keefektifan produk. Hasil dari produk Konseling Online adalah konseling melalui internet yang secara umum merujuk pada profesi yang berkaitan dengan layanan kesehatan mental melalui teknologi komunikasi internet. Konseling dikembangkan dengan menggunakan teknologi komunikasi dari yang paling sederhana menggunakan email, sesi dengan chat, sesi dengan telp pc-to-pc sampai penggunaan dengan penggunaan webcam (video live sessions), yang secara jelas menggunakan komputer dan internet. konseling online adalah klien dan konselor berkomunikasi dengan menggunakan streaming video dan audio.
\end{abstract}

Kata Kunci : Komputer, Internet, Konseling

ISSN 2715-0143 (online) ISSN 2714-9048 (print)

http://journal.walisongo.ac.id/index.php/jit/index 


\section{PENDAHULUAN}

Berkembangnya konseling melalui internet cukup besar di Indonesia. Apalagi cukup banyak pengakses internet dari kategori usia pelajar yang secara reguler browsing internet dan mengunjungi berbagai situs. Beberapa situs yang cukup popular saat ini misalnya seperti situs jejaring sosial seperti facebook, twitter, friendster, high5 dan lain sebagainya baik melaui PC, laptop, notebook dan juga telepon seluler. Salah satu alasan itulah yang menjadikan pengembangan konseling melalui internet bagi dunia pendidikan, perguruan tinggi pada khususnya, memiliki potensi menjadi hal yang mudah diterima bagi para pelajar atau mahasiswa.

Koutsonika

menyebutkan bahwa konseling online pertama kali muncul pada dekade 1960 dan 1970 dengan perangkat lunak program Eliza dan Parry, pada perkembangan awal konseling online dilakukan berbasis teks, dan sekarang sekitar sepertiga dari situs menawarkan konseling hanya melalui e-mail (Shaw \& Shaw dalam Koutsonika (2009)). Karena kemajuan teknologi metode lain juga digunakan seperti live chat, konseling telepon dan konseling video, sedangkan kata online diartikan adalah sebagai computer atau perangkat yang terhubung ke jaringan (seperti Internet) dan siap untuk digunakan atau digunakan oleh komputer atau perangkat lain (Business Dictionary, 2011).

Lebih lanjut dalam Wikipedia, online adalah dimaknai dalam jaringan atau daring atau keadaan saat sesuatu terhubung ke dalam suatu jaringan atau system (umumnya internet atau ethernet). Jadi istilah konseling online dapat dimaknai secara sederhana yaitu proses konseling yang dilakukan dengan alat bantu jaringan sebagai penghubung antara guru bk/konselor dengan kliennya. Hal ini senada dengan yang dikemukakan oleh (Amani, 2007) Konseling Online adalah konseling melalui internet yang secara umum merujuk pada profesi yang berkaitan dengan layanan kesehatan mental melalui teknologi komunikasi internet. Lebih lanjut Fields (2011) menyebutkan bahwa konseling online adalah layanan terapi yang relatif baru. Konseling dikembangkan dengan menggunakan teknologi komunikasi dari yang paling sederhana menggunakan email, sesi dengan chat, sesi dengan telp pc-to-pc sampai penggunaan dengan penggunaan webcam (video live sessions), yang secara jelas menggunakan komputer dan internet. Haberstroh (2011) menjelaskan bahwa konseling online adalah klien dan konselor berkomunikasi dengan menggunakan streaming video dan audio.

Bagi perguruan tinggi, khususnya yang memiliki lembaga konsultasi bimbingan dan konseling, kehadiran situs layanan konseling menjadi salah satu wujud "student support services" yang memberikan informasi dan bantuan berupa layanan konseling (Hamilton et.al: 2005). Fungsi lain dari media ini, juga dapat dijadikan sebagai sarana 
pendaftaran secara online untuk mendapatkan layanan konseling secara langsung di lembaga yang memberikan layanan konseling secara online melalui internet bagi mahasiswa yang mengalami kesulitan untuk berkonsultasi secara langsung melalui tatap muka.

Guna mewujudkan penerapkan layanan bimbingan dan konseling melalui internet diperlukan sebuah media yang terstandar dan disesuaikan dengan kebutuhan perguruan tinggi hingga ketersediaan teknologi yang dapat menunjangnya. Diperlukan juga tenaga-tenaga konselor yang terbiasa dengan pola interaksi dan komunikasi melalui internet. Hal tersebut merupakan penunjang penting dalam pelaksanaan penelitian ini, dimana peneliti akan mengembangkan sebuah media situs untuk memberikan layanan konseling melalui internet bagi mahasiswa perguruan tinggi.

Semenjak jejaring sosial menjadi bagian dari gaya hidup baru, dan internet menjadi medium komunikasi efektif dan efisien bagi para mahasiswa dan dosen yang telah menjadi bagian dari digital native. Hubungan dalam bingkai akademis dan ke- BK-an yang sebelumnya terbangun secara tatap-muka, juga telah terbawa hingga ke dunia maya. Facebook, Instant Messanger (IM), Email menjadi media yang cukup bisa diandalkan bagi mahasiswa untuk melakukan konsultasi psikologis dengan dosen yang juga konselor-nya. Sayangnya, hal tersebut tidak dilakukan dalam suatu media dan sistem yang dibangun secara sengaja. Sehingga kegiatan tersebut, seolaholah hanya kegiatan "curhat" rutin sehari-hari mahasiswa secara virtual, tanpa bingkai aspek etika yang mencerminkan profesionalitas konselor maupun aspek akademis yang membangun budaya ilmiah akademis yang baik. Salah satu alternatif pemecahan masalah tersebut adalah dengan mengembangakan suatu media yang dapat mewadahi layanan konseling secara profesional melalui internet yang sesuai dengan kaidah etika profesionalitas kerja konselor.

Media layanan konseling melalui internet merupakan suatu media yang secara khusus di desain untuk memenuhi kebutuhan layanan konsultasi psikologis bagi mahasiswa secara online. Media ini juga memberikan kemudahan bagi konselor dalam pengarsipan data dan menyimpan seluruh rekaman konseling. Data-data tersebut dapat mendorong dilakukannya penelitian ilmiah dalam bidang konseling dalam koridor yang pantas secara etika, sehingga melalui media ini juga konselor dituntut untuk bekerja dalam bingkai profesionalitas pada kerangka etika layanan konseling melalui internet.

\section{METODE}

Metode penelitian yang digunakan dalam Pengembangan Media Layanan Bimbingan Konseling Online Di Lbki Laboratorium Dakwah Dan Komunikasi UIN Walisongo Semarang adalah Metode Research and Development, metode penelitian 
yang digunakan untuk menghasilkan produk tertentu dan menguji keefektifan produk tersebut (Sugiono, 2013). Produk dimaksud adalah Aplikasi media layanan bimbingan dan konseling Online. Pengembangan Media Layanan Bimbingan Konseling Online itu sendiri melewati beberapa tahapan dari mulai potensi dan masalah sampai sistem tersebut dapat diterapkan, dioperasikan dan dipelihara.

\section{KERANGKA TEORI}

Guru BK/Konselor dapat bertemu dengan klien/konseli dengan menggunakan teknologi. Kondisi ini bertujuan untuk memudahkan konselor dalam membantu kliennya, memberikan kenyamanan kepada klien dalam bercerita dengan menggunakan aplikasi teknologi sebagai penghubung dirinya dengan konselor dengan tanpa harus tatap muka secara langsung.

\section{a) Website/Situs}

Dalam menyelenggarakan kon seling online guru bk/konselor da pat menyediakan sebuah alamat situ s. Situs ini menjadi alamat untuk melakukan praktik online, sehingga klien/konseli yang ingin melakukan konseling onl ine dapat berkunjung ke situs tersebut terlebih untuk selanjutnya melakukan konseling online.

Untuk dapat memiliki wesite konselor dapat berkerjasama deng an perusahaaan dan/atau para pakar bidang web developer. Konselor dapat memilih bentuk desaign web yang diinginkan mulai dari HTML, php dan website yang mengunakan CMS (Content management system)

b) Telephone/ Hand Phone Lebih sederhana konseling online dapat dilakukan dengan memanfaatkan telephone. Dimana konselor dan klien/konseli bisa dealing tehubung dengan menggunakan perangkat ini.

Telphone/handphone dapat digunakan untuk menghubungi konselor. konselor dapat mendengar dengan jelas apa yang diungkapkan kliennya melalui fasilitas telphone/handphone. Dengan fasilitas ini pula Konselor dengan segeranya dapat merespon apa yang dibicarakan oleh kliennya. Rosenfield and Smillie (dalam Mallen, 2011) menyebutkan bahwa dalam Studi kasus menunjukkan bahwa konseling dengan menggunakan telepon dapat berjalan efektif dalam membantu menangani individu dengan efek psikologis kanker

c) Email

Email merupakan singkatan dari Electronic Mail, yang berarti 'surat elektronik'. Email merupakan sistem yang memungkinkan pesan berbasis teks untuk dikirim dan diterima secara elektronik melalui beberapa komputer atau telepon seluler. Lebih spesifik lagi, email diartikan sebagai cara pengiriman data, file teks, foto digital, atau file-file audio dan video dari satu komputer ke komputer lainnya, dalam suatu jaringan komputer (intranet maupun internet). 
Ada banyak penyedia account email gratis seperti@yahoo, @gmail, @aim, @hotmail, @mail, @tekomnet, @plasa dan masih banyak yang lainnya.

d) Chat, Instant Messaging dan Jejaring sosial

Chat dapat diartikan sebagai obrolan, namun dalam dunia internet, istilah ini merujuk pada kegiatan komunikasi melalui sarana beberapa baris tulisan singkat yang diketikkan melalui keyboard. Sedangkan percakapan itu sendiri dikenal dengan istilah chatting. Percakapan ini bisa dilakukan dengan saling berinteraktif melalui teks, maupun suara dan video. Berbagai aplikasi dapat digunakan untuk chatting ini, seperti skype, messenger, google talk, window live messenger, mIRC, dan juga melalui jejaring sosial seperti facebook, twitter dan myspase yang didalamnya juga tersedia fasiltas chatting.

\section{e) Video Conferencing}

Video Conference, atau dalam bahasa Indonesia disebut video konferensi, atau pertemuan melalui video. Pertemuan ini dibantu oleh berbagai macam media jaringan seperti telepon ataupun media lainnya yang digunakan untuk transfer data video. Alat khusus video konferensi sangat mahal sehingga alternatif Konselor dan Klien dapat menggunakan fasilitas video konferensi yang terdapat pada beberapa aplikasi Instant Messaging yang didalamnya sudah menyediakan fasiltitas video call.
Secara spesifik, Marthin (2007) membagi dua jenis layanan dalam konseling melalui internet. Yaitu : 1. Non Interaktif berupa situs yang berisi informasi dan nara sumber self help atau pertolongan mandiri; 2 . Interaktif synchronous atau secara langsung seperti chat atau instant messaging, dan video conference, maupun interaktif asyncronous yang secara tidak langsung berupa terapi email atau email therapy dan Bulletin Boards Counseling (Maples \& Sumi: 2008).

Non Interaktif: situs konseling yang memberikan layanan non interaktif merupakan suatu bentuk layanan informasi atau jika kita kaitkan dengan bimbingan komprehensif merupakan salah satu bentuk layanan dasar (yang mendukung individu sebagai sebuah nara sumber yang berisi informasi bagi pengayaan diri dan bersifat self help bagi pribadi yang membutuhkan (Sampson et.al: 2004).

Interaktif: konseling yang berjenis interaktif adalah situs yang menawarkan alternatif bentuk terapi melalui internet, dimana terdapat interksi antara konseli dan konselor baik secara langsung atau synchronous ataupun tidak langsung asyncrhronous. Berikut pembagian jenis layanan yang ditawarkan dalam situs yang memberikan layanan dalam bentuk jenis interactive.

Synchronous: Merupakan media layanan konseling yang dilakukan secara langsung dan dalam waktu yang sebenarnya, bentuknya berupa pembicaraan melalui teks. pembicaraan melalui teks 
memberikan kesempatan kepada individu-individu untuk saling berkomunikasi secara dinamis dalam waktu yang sama melalui internet (Zack: 2004).

Asynchronous: merupakan layanan konseling interaktif akan tetapi tidak terjadi dalam waktu yang bersamaan. Dalam hal ini terdapat waktu tunda, antara pengungkapan permasalahan Konseli dengan respon yang diberikan oleh konselor. Terdapat dua bentuk layanan dalam metode konseling ini, yaitu terapi email dan Bulletin Boards Counseling (BBC). Terapi email merupakan suatu proses menulis tentang permasalahan yang dialami dan dirasakan oleh konseli yang bisa dijadikan sebagai bentuk terapetik bagi dirinya sendiri. Metode hubungan terapetik melalui email konseling, tidak mengenal waktu, artinya bisa dilakukan kapanpun, tidak mengenal tempat secara fisik, konseli tidak perlu mendatangi konselor, tetapi cukup berhubungan melalui internet. Bagi konselor sendiri, memiliki rekaman konseling yang cukup terperinci, karena semua tersimpan dalam bentuk data tertulis.

Dalam email konseling, konseli mengirimkan pesan melalui email kepada konselor mengenai permasalahan yang dihadapinya, kemudian konselor memberikan respon balik secara profesional melaui email. Konseling melalui email, memberikan pelayanan konseling yang lebih pribadi dalam hubungan satu sama lain antara konselor dengan konseli. Menurut Elleven dan Allen (2003), model komunikasi dalam bentuk ini lebih efisien, karena hampir seluruh konseli yang mencari bantuan layanan konseling melalui internet memilikinya. BBC adalah suatu sistem dimana Konseli mempublikasikan pertanyaanya di bulletin board, untuk selanjutkan konselor akan memberikan jawaban atau masukannya terhadap permasalahan konseli tersebut, bulletin board merupakan suatu ruang dimana seseorang dapat meninggalkan pesan dengan tetap merahasiakan identitasnya, dengan harapan akan memperoleh jawaban atau respon dari ruang publik yang ramah (Maples \& Sumi: 2008).

\section{DESAIN E-KONSELING FAKULTAS DAKWAH DAN KOMUNIKASI UIN WALISONGO SEMARANG}

Ada beberapa tahap yang harus dilakukan untuk membuat desain ekonseling Online, antara lain:

1. Lakukan pendaftaran dengan masuk ke situs https://www.mylivechat.com/

2. Lanjutkan pendaftaran dengan menekan start Now For Free, lakukan pengisian jangan sampai ada proses Sign Up yang terlewati, isilah sesuai dengan permintan pada situs tersebut.

3. Tekan Create Account Now

Jika proses pengisian sudah lengkap dan pendaftaran tunggu sampai muncul keterangan created successfully

4. Masukkan Coding E-Konseling setelah proses pendaftaran selesai, maka akan muncul coding 
yang harus dipindahkan ke Login website yang sudah ada, bentuk coding sebagai berikut:

<script type="text/javascript" async="async" defer $=" d e f e r "$

data-cfasync $=$ "false" src="https://mylivechat.com/ chatinline.aspx?hccid $=929238$ $83^{\prime \prime}></$ script $>$

Dengan masukkanya coding ke dalam Dashbaord di website, maka akan muncul tampilan Live Chat pada bagian depan website, yang diperlihatkan pada gambar $\mathrm{A}$.

Gambar A

Tampilan Live Chat

\section{Leave a message}

\section{Q9 Live Chat}

There are no agents available right now to take your call. Please leave a message and we will get back to you soon.

Name:

Email:

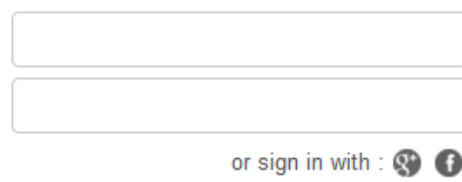

Subject:

Message:

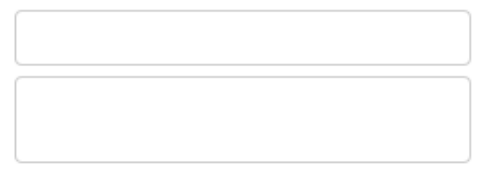

5. Lakukan proses login

Jika pendaftaran sudah selesai tahap berikutnya adalah masuk ke situs

https://www.mylivechat.com/ lakukan proses Account login untuk masuk ke Dashboard.

6. Lakukan proses konseling Untuk mengawali proses konseling lakukan dengan menekan chat now, yang diperlihatkan pada gambar $\mathrm{c}$.

Gambar C

Proses chat now dan Tampilan Mylivechat

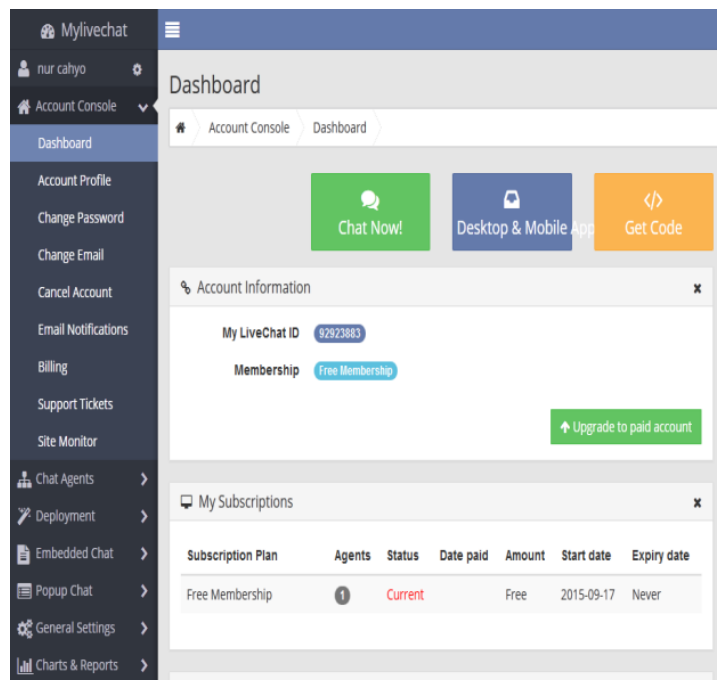

Buka alamat email

Ada keterangan dan informasi kode Mylive Chat Id, Email Address dan Password, yang diperlihatkan pada gambar $\mathrm{B}$.

\begin{tabular}{|r|}
\hline $\begin{array}{r}\text { MyLiveChat Id: } \\
\text { Email Address: }\end{array}$ \\
nur_cahyo@walisongo.ac.id \\
Password: $\mathbf{x x x x x x x x x}$ \\
Gambar B \\
Informasi kode Mylive Chat
\end{tabular}




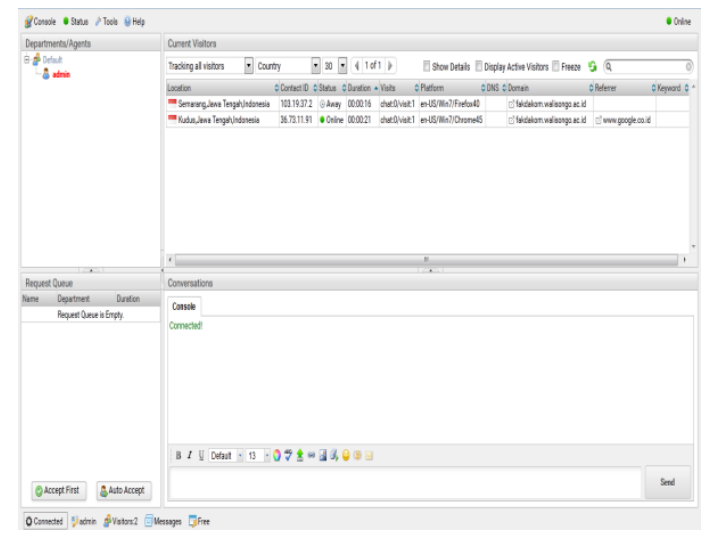

7. Proses chating

Langlah pertama dalam proses chating yaitu dengan mengisi nama dan email dari konseli serta dilengkapi dengan subject atau tema dari permasalahan yang dihadapai, sehingga memudahkan konselor untuk lebih cepat untuk memberikan solusi dari permasalahan yang dihadapi tiaptiap konseli. Jangan lupa untuk memasukkan pesan (message) yang terkait dengan subject, setelah lengkap silahkan tekan send. Pada saat konseli menekan send, maka preses selanjutnya menunggu respon dari admin konselor. Pada bagian admin ada nada dering yang menunjukkan ada konseli yang mengirimkan subject dan message akan sedang menunggu respon dari admin, setelah tanda tersebut di respon, maka proses chating dapat berjalan dengan baik antara konseli dengan konselor. Pada aplikasi bagian admin akan terlihat nama, lokasi, serta informasi detail dari konseli yang sedang melakukan chating dengan konselor. Pada pengisian form awal konseli bisa memilih beberapa konselor yang dikenali yang telah ditunjuk oleh Lembaga Bimbingan dan Konseling yang telah ditugasi menjadi konselor, dengan beberapa konselor yang berkompeten dibidangnya maka diharapkan permasalahan dari konseli dapat segera mendapatkan solusi, yang diperlihatkan pada gambar D.

Gambar D

Bentuk chating

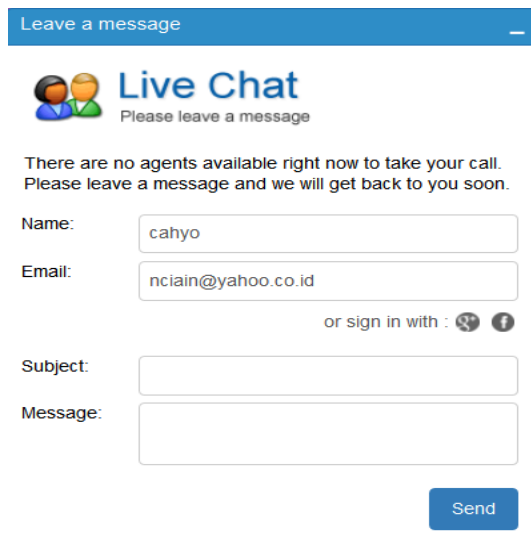




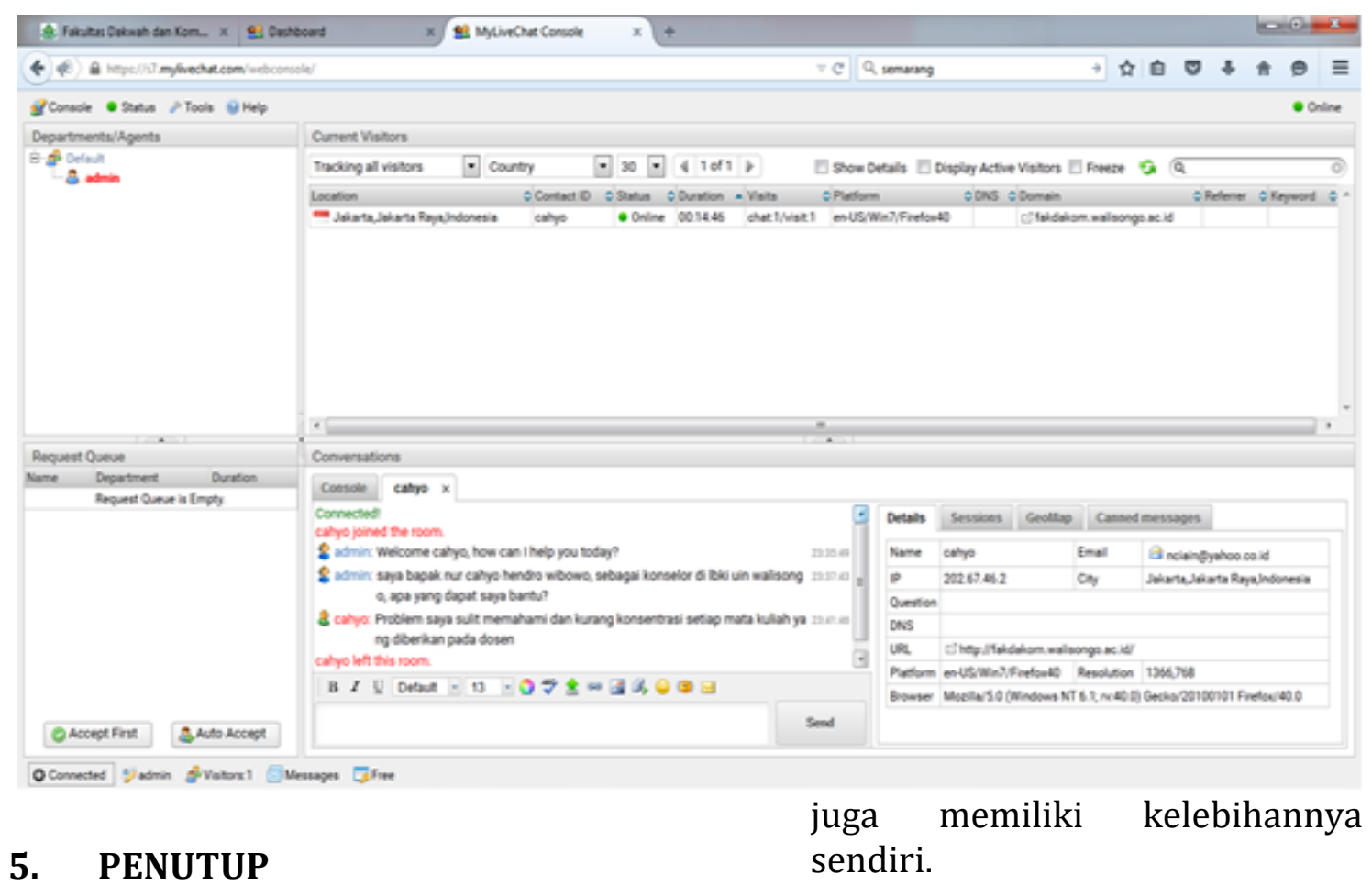
Penelitian masih terbatas pada pengembangan media layanan konseling melalui internet, sehingga masih diperlukan berbagai hal dan pengembangan lebih lanjut yang bisa dilakukan untuk meningkatkan layanan konseling melalui internet di LBKI Laboratoriun Dakwah pada Fakultas Dakwah dan Komunikasi.

Perlu adanya pelatihan yang intensif kepada guru atau dosen bk/konselor akan semakin melek teknologi, mampu menggunakan dan memanfaatkan teknologi informasi dan komunikasi.

Konseling melalui internet memiliki beberapa kekurangan jika dibandingkan dengan konseling secara tatap muka akan tetapi, konseling melalui internet 


\section{REFERENCES}

Ahmedani, B. K., Harold, R. D., Fitton, V. A., \& Shifflet Gibson, E. D. (2011). What adolescents can tell us: Technology and the future of social work education. Social Work Education, 30 (7), 830-846.

Amani, Nasanin (2007).: Investigating The Nature, The Prevalence, And Effectiveness Of Online Counseling, A Thesis, Department of Educational Psychology, Administration and Counseling, California State university Long Beach.

Belkin, Gary S. (1975). Practical Counseling in the School. USA: Wm. C. Brown Company Publishers

Capill, Lauren, ( $\mathrm{tt})$ Telecounselling and E-Counselling. Toronto : TAPE: Toronto Advances Profesional Education

Csiernik, R., Furze, P., Dromgole, L., \& Rishchynski, G. M. (2006). Information technology and social work - The dark side or light side? Journal of EvidenceBased Social Work, 3(3-4), 9-25.

Fields, Kenneth.

Online Counseling. www.openmmindcounseling.com.

(2011). About

Finn, J., \& Barak, A. (2010). A descriptive study of e-counsellor attitudes, ethics, and practice. Counselling and Psychotherapy Research, 10(4), 268-277.

Gibson, R.L. \& Mitchell, M.H. (2008). Introduction to Counseling and Guidance. New York: Macmillan Publisher.

Haberstroh, S (2009): Strategies and Resources for Conducting Online Counseling, Journal of Professional Counseling: Practice, Theory, And Research Vol. 37, No.2, Fall/Winter 2009

Haberstroh, S., \& Duffey, T. (2011). Face-to-face supervision of online counselors: Supervisor perspectives. Retrieved from http://counselingoutfitters.com/vistas/vistas11/ Article_66.pdf

Ifdil. (2009). Pelayanan e-Konseling (Pengolahan Hasil Pengadministrasian Alat Ungkap Masalah (AUM) dengan Menggunakan Program Aplikasi). Paper presented at the Seminar Internasional Bimbingan dan Konseling Dalam rangka Kongres XI dan Konvensi Nasional XVI ABKIN

Ifdil. (2011). Penyelenggaraan Layanan Konseling Online Sebagai Salah Satu Bentuk Pelayanan E-Konseling. Paper presented at the International Seminar \& Workshop Contemporary and Creative Caunseling.

Koutsonika, Helen (2009) E-Counseling: the new modality. Online Career Counseling - a challenging opportunity for greek tertiary education. In: 
Proceedings of the WebSci'09: Society On-Line, 18-20 March 2009, Athens, Greece. (In Press)

Lievrouw, L. A. (2010). Social media and the production of knowledge: A return to little science? Social Epistemology, 24(3), 219-237.

Mallen, Michael J. David L. Vogel, dkk. (2011). Online Counseling, Reviewing the Literature From a Counseling Psychology Framework:, The Counseling Psychologist, Vol. 33 No. 6, November 2005. Houston: the Society of Counseling Psychology.

National Board for Certified Counselors, Inc. and Center for Credentialing and Education, Inc., (tt) The Practice of Internet Counseling.

Prayitno dan Erman Amti. (2004). Dasar-Dasar Bimbingan Konseling. Cetakan ke dua.

Prayitno. 2004. Konseling Pancawaskita. Padang: FIP

Prayitno. (2004). Seri Layanan Konseling. L.5 (Layanan Konseling Perorangan). Padang: FIP. Jurusan BK. UNP.

Shertzer, B. \& Stone, S.C. (1976). Fundamental of Gudance. Boston : HMC

Winkel, W.S, 2005. Bimbingan dan Konseling di Intitusi Pendidikan, Edisi Revisi. Jakart a: Gramedia

Zamani, Z. A. (2009). Computer technology and counseling. Paper presented the International Conference on Computer Science and Information Technology, ICCSIT 2009.

Zamani, Z. A., Nasir, R., \& Yusooff, F. (2010). Perceptions towards online counseling among counselors in Malaysia. Procedia Social and Behavioral Sciences 5, 585-589.

Zeng, W., Yi, C., Chen, H., \& Xin, R. (2010). Web peer counseling system. Paper presented at the International Conference on Educational and Information Technology.

Yanmi, A. (2019). Improved thematic learning outcomes used the STAD type cooperative model. Jurnal Konseling dan Pendidikan, 7(1). DOI: https://doi.org/10.29210/128600. 
Hendro Nur Cahyo Hendro Wibowo ${ }^{1}$, Flora Ima Milenia ${ }^{2}$, Faris Hifzhuddin Azmi ${ }^{3}$

This page intentionally left blank.

24 | WJIT : Walisongo Journal of Information Technology - Vol.1 No. 1 (2019) 